osvity spetsialnosti 072 Finansy, bankivska sprava ta strakhuvannia osvitno-profesiinoi prohramy «Finansy, bankivska sprava ta strakhuvannia». Lutskyi natsionalnyi tekhnichnyi universytet. Lutsk, 2020.

2. Nikolaieva A.M., Ishchuk L.I. Efektyvne vykorystannia biudzhetnykh koshtiv u systemi sotsialno-ekonomichnoho rozvytku rehioniv. Ekonomichnyi forum. Nauk. zh-1. 2018. №4. S. 116-121.

3. Departament finansiv Volynskoi oblasnoi derzhavnoi administratsii. Ofitsiinyiveb-sait URL: http://www.finance.voladm.gov.ua/articles/id-493/ (data zvernennia: 20.09.2020).

4. Novytska N.V., Khliebnikova I.I., Korotun V.I., Koshchuk T.V. Modernizatsiia systemy kontroliu za obihom tiutiunovykh vyrobiv / zazah. red. Novytskoi N.V. Irpin. Khmelnytskyi, 2020. $120 \mathrm{~s}$.

5. Yak pratsiuie nelehalnyi rynok naftoproduktiv v Ukraini URL: https://mind.ua/publications/20194305-yak-pracyuenelegalnij-rinok-naftoproduktiv-v-ukrayini/ (data zvernennia: 10.11.2020).

6. Subochev O. Rynok alkoholnoi produktsii URL: https://rating.zone/rynok-alkoholnoi-produktsii/ (data zvernennia: 10.11.2020).

Дата подання публікації 13.12.2020 p.

УДК 332.133:339.3

Ковальська Л.Л., д.е.н., проф., завідувач кафедри підприємництва, торгівлі та

біржової діяльності

D.Sc. (Economics), Professor, Head of Department, Professor of the Department of Entrepreneurship, Trade and Exchange Activities, https://orcid.org/0000-0003-2924-9857

Голодюк Г.І., к.т.н., доцент кафедри товарознавства та експертизи в митній справі Galina Golodyuk, Docent Department of Commodity Science and Expertise in Customs https://orcid.org/0000-0002-9740-5498

Кривов'язюк Б.І. Kryvovyazyuk B.

\title{
АНАЛІТИЧНЕ ДОСЛІДЖЕННЯ РОЗВИТКУ ПІДПРИЕМНИЦТВА РЕГІОНІВ ДЕРЖАВИ У СФЕРІ ТОРГІВЛІ
}

\author{
Луцький національний технічний університет
}

У статті проведено аналітичне дослідження розвитку підприємництва в сфері торгівлі. Проаналізовано передумови забезпечення розвитку підприємництва в сфері торгівлі. Зокрема, такі показники як кількість підприємств за видами економічної діяльності; кількість підприємств, які здійснювали діяльність із роздрібної торгівлі за видами економічної діяльності; кількість об'єктів торгівлі (загалом, у містах та селищах міського типу, у сільській місцевості); торгова мережа об'єктів роздрібної торгівлі (в розрізі магазинів, аптек та автозаправних станцій); забезпеченість об'єктами роздрібної торгівлі (всього, магазинами, торговою площею). Здійснено аналіз результатів розвитку підприємництва в сфері торгівлі. У даному напрямів проаналізовано такі показники як оборот роздрібної торгівлі; роздрібний товарооборот підприємств роздрібної торгівлі за видами економічної діяльності; індекси фізичного обсягу роздрібного товарообороту підприємств роздрібної торгівлі. Проведено комплексну оцінку розвитку підприємництва регіонів держави в сфері торгівлі. Здійснено групування регіонів держави за рівнем передумов, результатів та розвитку підприємництва в сфері торгівлі. Аналітичні дослідження показали, що найвищий рівень розвитку підприємництва у сфері торгівлі спостерігається у м. Києві. До групи регіонів із середнім рівнем розвитку підприємництва в сфері торгівлі віднесено Донецьку, Київську, Львівську, Одеську, Харківську області. Такі регіони держави як Вінницька, Волинська, Дніпропетровська, Житомирська, Закарпатська, Запорізька, Івано-Франківська, Кіровоградська, Луганська, Миколаївська, Полтавська, Рівненська, Сумська, Херсонська, Хмельницька, Черкаська, Чернівецька, Чернігівська області потрапили до групи із низьким рівнем розвитку підприємництва в сфері торгівлі. Узагальнено висновки, що спостерігається група регіонів, які володіють потенційними 
можливостями та передумовами щодо забезпечення високого рівня розвитку підприємництва в сфері торгівлі та водночас, мають невисокі показники результативності, що вказує на необхідність прийняття обгрунтованих рішень по підвищенню ефективності їх використання.

Ключові слова: регіон, підприємництво, торгівля, роздрібна торгівля, роздрібна торговельна мережа, аналіз, оичнка, передумови, результати.

\title{
ANALYTICAL STUDY OF THE DEVELOPMENT OF ENTREPRENEURSHIP IN THE REGIONS OF THE STATE IN THE FIELD OF TRADE
}

\author{
Луцький наџіональний технічний університет
}

The article provides an analytical study of the development of entrepreneurship in the field of trade. The prerequisites for ensuring the development of entrepreneurship in the field of trade are analysed. In particular, such indicators as the number of enterprises by type of economic activity; the number of enterprises that carried out retail trade activities by type of economic activity; the number of trade objects (in general, in cities and urban-type settlements, in rural areas); the retail network of retail trade objects (by stores, pharmacies and gas stations); availability of retail facilities (total, shops, retail space) were analysed. The analysis of the results of entrepreneurship development in the field of trade is carried out. In this direction, such indicators as retail trade turnover; retail trade turnover of retail trade enterprises by type of economic activity; indices of the physical volume of retail trade turnover of retail trade enterprises are analysed. A comprehensive assessment of the development of entrepreneurship in the regions of the state in the field of trade was carried out. The regions of the state are grouped according to the level of prerequisites, results and development of entrepreneurship in the field of trade. Analytical studies have shown that the highest level of entrepreneurship development in the field of trade is observed in Kyiv. The group of regions with an average level of entrepreneurship development in the field of trade includes Donetsk, Kyiv, Lviv, Odesa, and Kharkiv regions. Such regions of the state as Vinnytsia, Volyn, Dnipropetrovsk, Zhytomyr, Zakarpattia, Zaporizhia, Ivano-Frankivsk, Kirovohrad, Luhansk, Mykolaiv, Poltava, Rivne, Sumy, Kherson, Khmelnytsky, Cherkasy, Chernivtsi, Chernihiv regions were included in the group with a low level of entrepreneurship development in the field of trade. Generalized conclusions were made that there is a group of regions that have potential opportunities and prerequisites for ensuring a high level of business development in the field of trade and at the same time have low performance indicators, which indicates the need to make informed decisions to improve the efficiency of their use.

Key words: region, entrepreneurship, trade, retail trade, retail trade network, analysis, evaluation, background, results

Постановка проблеми у загальному вигляді та ії зв'язок із важливими науковими чи практичними завданнями. Підприємництво в сфері торгівлі $\epsilon$ динамічним процесом, який залежить від багатьох умов та чинників. 3 іншої сторони, підприємництво в сфері торгівлі визначає особливості розвитку регіональної та національної економік, вектори їх стратегічної орієнтації та рівень конкурентоспроможності. Тому, важливим є дослідження особливостей розвитку підприємництва в сфері торгівлі, визначення проблем у його забезпеченні, а також напрямів подальшого функціонування. Це вимагає проведених відповідних аналітичних досліджень розвитку підприємництва регіонів держави в сфері торгівлі, оцінки тенденцій у ретроспективному та поточному періодах.

Аналіз останніх досліджень і публікацій, в яких започатковано розв'язання даної проблеми. У напрацюваннях науковців ведуться дискусії з приводу розвитку підприємництва в сфері торгівлі. Одні науковці акцентують увагу на розвитку підприємництва як такого (Васільєва Л. [1], Власова Н. [2], Сизоненко В. [3]), інші ж науковці основну свою увагу зосереджують на розвитку торговельних відносин (Андросова Т. [4], Бурак I. [5], Власова Н. [6]); ще інші науковці пробують об'єднати ці два поняття i розглядають особливості розвитку комерційного підприємництва (Панкратов Ф. [7], Саблук О. [8]) та його вплив на економіку регіону та країни в цілому. Проте, і досі залишаються актуальними питання забезпечення розвитку підприємництва в сфері торгівлі та виявлення регіональних особливостей його здійснення.

Цілі статті. Метою дослідження є здійснення аналітичних досліджень розвитку підприємництва регіонів держави в сфері торгівлі. 
Виклад основного матеріалу дослідження 3 повним обгрунтуванням отриманих наукових результатів. Аналіз та оцінку розвитку підприємництва регіонів держави в сфері торгівлі пропонуємо проводити у двох напрямах: аналіз та оцінка передумов забезпечення розвитку підприємництва в сфері торгівлі; аналіз та оцінка результатів розвитку підприємництва в сфері торгівлі.

Аналіз та оцінка передумов забезпечення розвитку підприємництва регіонів держави в сфері торгівлі передбачає аналіз таких показників як: кількість підприємств за видами економічної діяльності; кількість підприємств, які здійснювали діяльність із роздрібної торгівлі за видами економічної діяльності; кількість об'єктів торгівлі (загалом, у містах та селищах міського типу, у сільській місцевості); торгова мережа об’єктів роздрібної торгівлі (в розрізі магазинів, аптек та автозаправних станцій); забезпеченість об'єктами роздрібної торгівлі (всього, магазинами, торговою площею).

Проаналізуємо ці показники. Найбільша кількість суб'єктів господарювання, які займалися підприємництвом припадає на такі регіони як Дніпропетровська (698 од.), Львівська (1066 од.), Харківська (699 од.), Вінницька (649 од.), Київська (830 од.) області, м. Київ (1036 од.). Натомість, найменше суб'єктів підприємницької діяльності зареєстровано у Луганській (155 од.), Рівненській (257 од.), Миколаївській (268 од.), Чернівецькій (201 од.) областях. Із усієї сукупності підприємств, що здійснюють підприємницьку діяльність, найбільша частка підприємств оптової та роздрібної торгівлі автотранспортними засобами та мотоциклами, їх ремонт припадає на такі регіони як Волинська $(14,2 \%)$, Дніпропетровська $(11,2 \%)$, Закарпатська $(10,2 \%)$, Полтавська (10,4\%), Херсонська $(10,1 \%)$ області, м. Київ $(9,6 \%)$.

Водночас, слід зауважити, що великий відсоток підприємств припадає на інші види роздрібної торгівлі, де частка по регіонах держави коливається в межах 40\%-70\%. Найбільший відсоток припадає на Чернівецьку область (73,7\% від загальної кількості підприємств), Чернігівську область (73,7\% від загальної кількості підприємств), Київську область (74,6\%).

В цілому, в Україні 889 одиниць здійснювали діяльність, пов'язану із оптовою та роздрібною торгівлею автотранспортними засобами та мотоциклами, їх ремонт, що складає 7,4\% від усієї сукупності підприємств. Оптовою торгівлею, крім автотранспортних засобів займались 981 підприємство, що становить 8,1\% від загальної кількості підприємств. Найбільше суб'єктів підприємництва припадає на роздрібну торгівлю, зокрема це 7789 підприємств, що становить 64,6\% від загальної кількості усіх підприємств.

Найбільша частка підприємств торгівлі припадає на міста та селища міського типу, що становить більш як 60\% від загальної кількості підприємств, що займаються торгівлею. Із загальної сукупності підприємств торгівлі 32662 одиниць припадало на магазини, що становить $83 \%$. Торгова площа магазинів становила 7031 тис. м ${ }^{2}$. Таким чином, забезпеченість населення у розрахунку на 10000 осіб торговою площею магазинів становила на 1 січня 2018 року $1659 \mathrm{~m}^{2}$.

Зупинимось більш детальніше на аналіз та оцінці кількості об’єктів роздрібної торгівлі у регіональному розрізі за період 2014-2018 років (табл. 1). Аналізуючи та оцінюючи динаміку кількості об'єктів роздрібної торгівлі, слід відмітити негативну динаміку щодо їх приросту за період 2014-2018 років. В цілому, по Україні у 2014 році було 49607 одиниць-торговельних об'єктів, у 2018 році вже стало 39305 об'єктів роздрібної торгівлі. При чому, за цей же період у містах та селищах міського типу кількість об'єктів знизилась на 6867 одиниць, а у сільській місцевості на 3435 одиниць.

У регіональному розрізі найбільша кількість об'єктів роздрібної торгівлі спостерігалась у Дніпропетровській (3073 од. у 2018 році), Київській (2539 од. у 2018 році), Львівській (3098 од. у 2018 році), Одеській (2286 од. у 2018 році), Харківській (3228 од. у 2018 році) областях та м. Києві (3983 од. у 2018 році). 
Таблиця 1. Кількість об'єктів роздрібної торгівлі регіонів держави за період 2014-2018 років

\begin{tabular}{|c|c|c|c|c|c|c|c|c|c|c|c|c|c|c|c|}
\hline & \multicolumn{5}{|c|}{ Усього } & \multicolumn{5}{|c|}{ У містах та селищах міського типу } & \multicolumn{5}{|c|}{ У сільській місцевості } \\
\hline & 2014 & 2015 & 2016 & 2017 & 2018 & 2014 & 2015 & 2016 & 2017 & 2018 & 2014 & 2015 & 2016 & 2017 & 2018 \\
\hline Україна & 49607 & 49587 & 49326 & 42546 & 39305 & 38743 & 39268 & 39391 & 23400 & 31876 & 10864 & 10319 & 9935 & 19146 & 7429 \\
\hline Вінницька & 1969 & 1945 & 1921 & 1765 & 1650 & 951 & 1012 & 1062 & 618 & 930 & 1018 & 933 & 859 & 1147 & 720 \\
\hline Волинська & 1419 & 1356 & 1324 & 1134 & 983 & 963 & 959 & 969 & 714 & 715 & 456 & 397 & 355 & 420 & 268 \\
\hline Дніпропетровська & 3637 & 3686 & 3729 & 3341 & 3073 & 3244 & 3345 & 3405 & 2506 & 2841 & 393 & 341 & 324 & 835 & 232 \\
\hline Донецька & 1981 & 1692 & 1603 & 1409 & 1328 & 1789 & 1529 & 1469 & 546 & 1225 & 192 & 163 & 134 & 863 & 103 \\
\hline Житомирська & 1662 & 1633 & 1616 & 1450 & 1284 & 1128 & 1148 & 1171 & 522 & 945 & 534 & 485 & 445 & 928 & 339 \\
\hline Закарпатська & 1242 & 1286 & 1245 & 1087 & 927 & 723 & 798 & 793 & 478 & 650 & 519 & 488 & 452 & 609 & 277 \\
\hline Запорізька & 2241 & 2242 & 2198 & 1879 & 1628 & 1881 & 1926 & 1880 & 1259 & 1422 & 360 & 316 & 318 & 620 & 206 \\
\hline Івано-Франківська & 1460 & 1430 & 1391 & 1154 & 922 & 1035 & 1049 & 1039 & 519 & 705 & 425 & 381 & 352 & 635 & 217 \\
\hline Київська & 2757 & 2916 & 2928 & 2790 & 2539 & 1712 & 1822 & 1768 & 1562 & 1531 & 1045 & 1094 & 1160 & 1228 & 1008 \\
\hline Кіровоградська & 1439 & 1478 & 1494 & 1354 & 1118 & 1071 & 1124 & 1144 & 515 & 830 & 368 & 354 & 350 & 839 & 288 \\
\hline Луганська & 566 & 514 & 519 & 498 & 442 & 473 & 443 & 449 & 324 & 380 & 93 & 71 & 70 & 174 & 62 \\
\hline Львівська & 3781 & 3848 & 3865 & 3576 & 3098 & 3137 & 3238 & 3253 & 2324 & 2623 & 644 & 610 & 612 & 1252 & 475 \\
\hline Миколаївська & 1358 & 1351 & 1428 & 1389 & 1154 & 1060 & 1059 & 1135 & 778 & 910 & 298 & 292 & 293 & 611 & 244 \\
\hline Одеська & 3038 & 3010 & 3032 & 2769 & 2286 & 2627 & 2609 & 2662 & 1274 & 2020 & 411 & 401 & 370 & 1495 & 266 \\
\hline Полтавська & 1891 & 1889 & 1916 & 1765 & 1575 & 1323 & 1352 & 1398 & 865 & 1171 & 568 & 537 & 518 & 900 & 404 \\
\hline Рівненська & 1475 & 1460 & 1469 & 1356 & 1192 & 862 & 869 & 884 & 732 & 808 & 613 & 591 & 585 & 624 & 384 \\
\hline Сумська & 1237 & 1209 & 1143 & 1098 & 914 & 923 & 896 & 864 & 714 & 739 & 314 & 313 & 279 & 384 & 175 \\
\hline Тернопільська & 1067 & 1133 & 1102 & 1032 & 801 & 658 & 739 & 735 & 402 & 538 & 409 & 394 & 367 & 630 & 263 \\
\hline Харківська & 3589 & 3653 & 3710 & 3541 & 3228 & 3368 & 3434 & 3485 & 2302 & 3064 & 221 & 219 & 225 & 1239 & 164 \\
\hline Херсонська & 1301 & 1348 & 1344 & 1293 & 1031 & 1036 & 1087 & 1111 & 724 & 849 & 265 & 261 & 233 & 569 & 182 \\
\hline Хмельницька & 1769 & 1782 & 1819 & 1658 & 1334 & 1215 & 1253 & 1297 & 746 & 957 & 554 & 529 & 522 & 912 & 377 \\
\hline Черкаська & 1569 & 1524 & 1519 & 1482 & 1065 & 1133 & 1111 & 1115 & 815 & 833 & 436 & 413 & 404 & 667 & 232 \\
\hline Чернівецька & 869 & 891 & 886 & 764 & 621 & 628 & 637 & 635 & 435 & 448 & 241 & 254 & 251 & 329 & 173 \\
\hline Чернігівська & 1440 & 1461 & 1417 & 1270 & 1129 & 953 & 979 & 960 & 699 & 759 & 487 & 482 & 457 & 572 & 370 \\
\hline м. Київ & 4850 & 4850 & 4708 & 4361 & 3983 & 4850 & 4850 & 4708 & 2442 & 3983 & - & - & - & 1919 & - \\
\hline
\end{tabular}


Натомість, найменше їх було у Волинській (983 од. у 2018 році), Закарпатській (927 од. у 2018 році), Івано-Франківській (922 од. у 2018 році), Луганській (442 од. у 2018 році), Сумській (913 од. у 2018 році), Тернопільській (801 од. у 2018 році), Чернівецькій (621 од. у 2018 році) областях.

Аналізуючи темп росту (приросту) кількості об'єктів роздрібної торгівлі регіонів держави за період 2014-018 років (рис. 1), слід зауважити, що в усіх регіонах без винятку відбулося скорочення кількості об'єктів роздрібної торгівлі за аналізований період. Найбільше скорочення відбулося у таких регіонах як Волинській (на 30,7\%), Донецькій (на 33\%), Івано-Франківській (на 36,8\%), Черкаській областях (на 32,1\%). Найменше скорочення кількості об'єктів роздрібної торгівлі спостерігалось у Київській $(7,9 \%)$, Харківській $(10,1 \%)$ областях.

Проаналізуємо забезпеченість населення об'єктами роздрібної торгівлі (табл. 2). Аналізуючи динаміку, можемо спостерігати зниження рівня забезпеченості населення об'єктами роздрібної торгівлі, зокрема щодо кількості об'єктів торгівлі та торговельної площі на 10000 осіб населення. Найбільший рівень забезпеченості населення об'єктами торгівлі у регіональному вимірі припадає на Київську область (15 об'єктів всього, з них 12 магазинів), м. Київ (14 об’ єктів всього, з них 12 магазинів), Кіровоградська, Львівська, Харківська області, на які припадало по 12 об'єктів роздрібної торгівлі. Регіонамиаутсайдерами у 2018 році по забезпеченню населення об'єктами роздрібної торгівлі $\epsilon$ Донецька (3 од.), Закарпатська (7 од.), Запорізька (9 од.), Івано-Франківська (7 од.), Луганська (2 од.), Чернівецька (8 од.) області. Найменша забезпеченість магазинами спостерігається у Донецькій (3 од.), Луганській (2 од.), Чернівецькій (6 од.) областях.

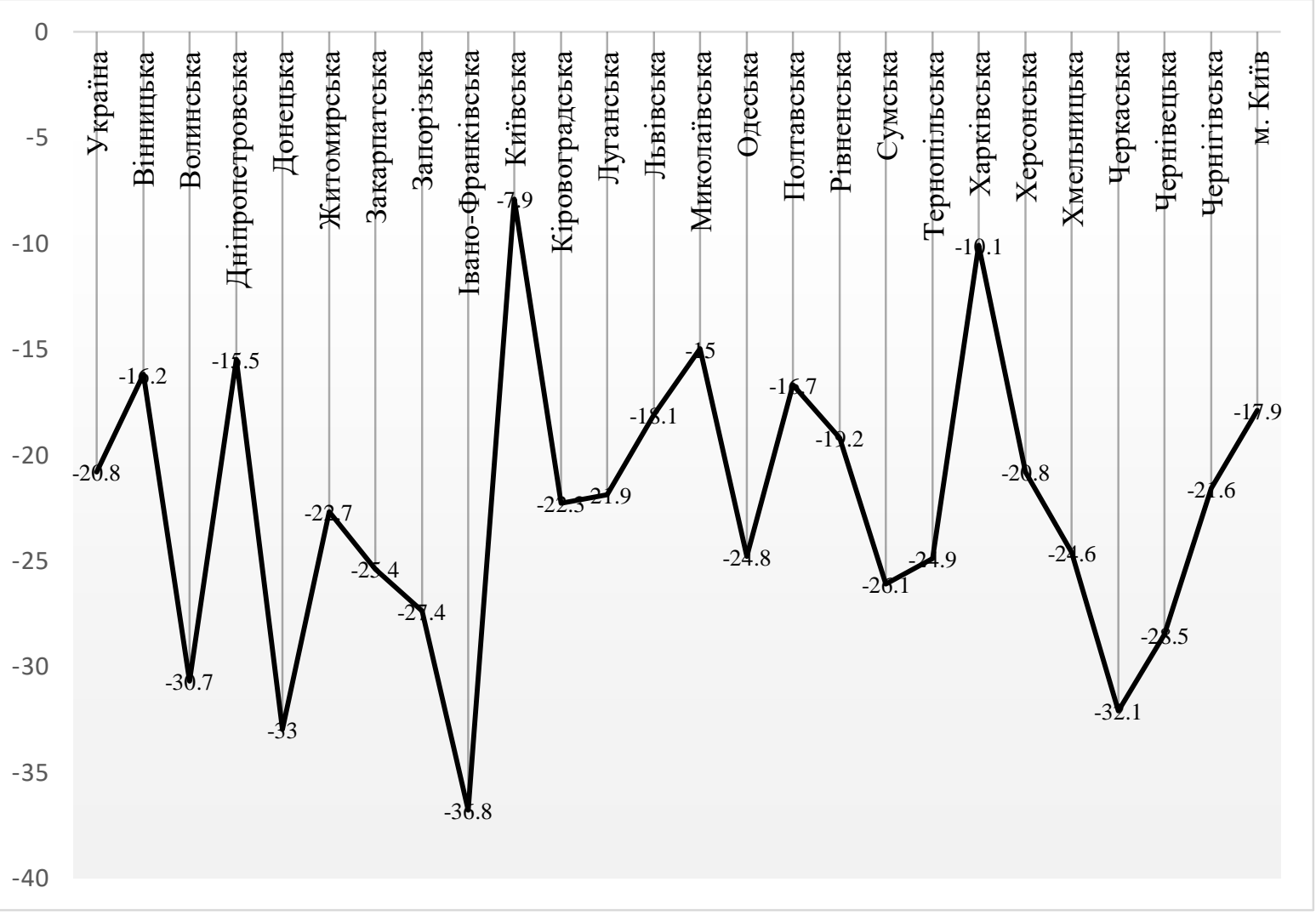

Рис. 1. Схематичне відображення темпів росту (приросту) кількості об'єктів роздрібної торгівлі регіонів держави за період 2014-2018 років 
Таблиця 2. Забезпеченість населення об'єктами роздрібної торгівлі

\begin{tabular}{|c|c|c|c|c|c|c|c|c|c|c|c|c|c|c|c|}
\hline \multirow[t]{2}{*}{ Регіони } & \multicolumn{5}{|c|}{$\begin{array}{c}\text { Об'єктами торгівлі (магазинами, } \\
\text { кіосками, автозаправними станціями) }\end{array}$} & \multicolumn{5}{|c|}{3 них магазинами } & \multicolumn{5}{|c|}{ Торговою площею магазинів, м² } \\
\hline & 2014 & 2015 & 2016 & 2017 & 2018 & 2014 & 2015 & 2016 & 2017 & 2018 & 2014 & 2015 & 2016 & 2017 & 2018 \\
\hline Україна & 12 & 12 & 12 & 10 & 9 & 9 & 9 & 9 & 9 & 8 & 1806 & 1805 & 1808 & 1812 & 1659 \\
\hline Вінницька & 12 & 12 & 12 & 11 & 11 & 10 & 10 & 10 & 10 & 9 & 1254 & 1303 & 1318 & 1324 & 1299 \\
\hline Волинська & 14 & 13 & 13 & 11 & 9 & 11 & 10 & 10 & 10 & 9 & 1531 & 1562 & 1538 & 1540 & 1387 \\
\hline Дніпропетровська & 11 & 11 & 12 & 10 & 10 & 9 & 9 & 9 & 9 & 8 & 2205 & 2232 & 2171 & 2170 & 1969 \\
\hline Донецька & 5 & 4 & 4 & 3 & 3 & 4 & 3 & 3 & 3 & 3 & 1020 & 590 & 547 & 550 & 468 \\
\hline Житомирська & 13 & 13 & 13 & 12 & 10 & 11 & 11 & 10 & 11 & 9 & 1283 & 1288 & 1319 & 1324 & 1239 \\
\hline Закарпатська & 10 & 10 & 10 & 9 & 7 & 8 & 8 & 7 & 7 & 6 & 1411 & 1446 & 1466 & 1466 & 1360 \\
\hline Запорізька & 13 & 13 & 13 & 11 & 9 & 10 & 10 & 10 & 10 & 8 & 1779 & 1943 & 1857 & 1865 & 1658 \\
\hline Івано-Франківська & 11 & 10 & 10 & 8 & 7 & 8 & 8 & 8 & 8 & 6 & 1219 & 1204 & 1216 & 1217 & 1121 \\
\hline Київська & 16 & 17 & 17 & 16 & 15 & 12 & 13 & 13 & 13 & 12 & 2438 & 2602 & 2747 & 2732 & 2647 \\
\hline Кіровоградська & 15 & 15 & 15 & 14 & 12 & 12 & 12 & 12 & 12 & 11 & 1407 & 1412 & 1461 & 1469 & 1344 \\
\hline Луганська & 3 & 2 & 2 & 2 & 2 & 2 & 2 & 2 & 2 & 2 & 330 & 241 & 242 & 244 & 268 \\
\hline Львівська & 15 & 15 & 15 & 14 & 12 & 12 & 12 & 12 & 12 & 11 & 1725 & 1808 & 1842 & 1844 & 1670 \\
\hline Миколаївська & 12 & 12 & 12 & 12 & 10 & 8 & 8 & 9 & 9 & 7 & 1798 & 1874 & 1804 & 1811 & 1574 \\
\hline Одеська & 13 & 13 & 13 & 12 & 10 & 10 & 10 & 10 & 10 & 8 & 2439 & 2615 & 2670 & 2672 & 2607 \\
\hline Полтавська & 13 & 13 & 13 & 12 & 11 & 10 & 11 & 11 & 11 & 9 & 1665 & 1636 & 1651 & 1659 & 1399 \\
\hline Рівненська & 13 & 13 & 13 & 12 & 10 & 10 & 10 & 10 & 10 & 9 & 1728 & 1536 & 1542 & 1544 & 1382 \\
\hline Сумська & 11 & 11 & 10 & 10 & 8 & 9 & 9 & 9 & 9 & 7 & 1524 & 1502 & 1454 & 1461 & 1396 \\
\hline Тернопільська & 10 & 11 & 10 & 10 & 8 & 8 & 8 & 8 & 8 & 6 & 1021 & 1052 & 1102 & 1106 & 926 \\
\hline Харківська & 13 & 13 & 14 & 13 & 12 & 8 & 9 & 9 & 9 & 8 & 2092 & 2128 & 2158 & 2160 & 2002 \\
\hline Херсонська & 12 & 13 & 13 & 12 & 10 & 10 & 10 & 10 & 10 & 8 & 1960 & 1983 & 1978 & 1986 & 1724 \\
\hline Хмельницька & 14 & 14 & 14 & 13 & 10 & 11 & 11 & 11 & 12 & 9 & 1631 & 1639 & 1687 & 1694 & 1500 \\
\hline Черкаська & 13 & 12 & 12 & 12 & 9 & 9 & 9 & 9 & 9 & 7 & 1420 & 1323 & 1284 & 1290 & 1127 \\
\hline Чернівецька & 10 & 10 & 10 & 8 & 7 & 7 & 8 & 7 & 7 & 6 & 1191 & 1223 & 1309 & 1310 & 1119 \\
\hline Чернігівська & 14 & 14 & 14 & 12 & 11 & 11 & 11 & 11 & 11 & 10 & 1527 & 1645 & 1602 & 1612 & 1434 \\
\hline м. Київ & 17 & 17 & 16 & 15 & 14 & 13 & 13 & 13 & 13 & 12 & 4784 & 4945 & 4888 & 4881 & 4452 \\
\hline
\end{tabular}


Найбільше торговельної площі на 10 тис. осіб населення у 2018 році припадало

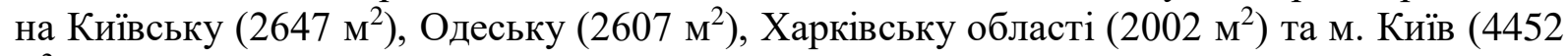
$\left.\mathrm{M}^{2}\right)$.

Слід зауважити, що зниження рівня забезпеченості об’єктів роздрібної торгівлі характеризує негативні аспекти розвитку підприємництва у сфері торгівлі.

Аналіз та оцінку результатів розвитку підприємництва регіонів держави в сфері торгівлі проведемо за наступною системою показників:

-оборот роздрібної торгівлі;

-роздрібний товарооборот підприємств роздрібної торгівлі за видами економічної діяльності;

-індекси фізичного обсягу роздрібного товарообороту підприємств роздрібної торгівлі.

Таблиця 3 - Оборот роздрібної торгівлі, млн грн

\begin{tabular}{|c|c|c|c|c|c|c|c|}
\hline \multirow[t]{2}{*}{ Регіони } & \multicolumn{5}{|c|}{ Роки } & \multicolumn{2}{|c|}{$\begin{array}{l}\text { Відхилення, } \\
\text { 2014/2018 рр. }\end{array}$} \\
\hline & 2014 & 2015 & 2016 & 2017 & 2018 &,+- & $\%$ \\
\hline Україна & 901924 & 1031679 & 1175319 & 815344,3 & 930629,2 & 28705,2 & 3,2 \\
\hline $\begin{array}{l}\text { Автономна } \\
\text { Республіка Крим }\end{array}$ & - & - & - & - & - & - & - \\
\hline Вінницька & 29264 & 34509 & 38400 & 21049,1 & 25658,4 & $-3605,6$ & $-12,3$ \\
\hline Волинська & 21476 & 27154 & 28827 & 15256,9 & 16334,0 & -5142 & $-23,9$ \\
\hline Дніпропетровська & 80419 & 94928 & 106421 & 72542,1 & 85302,9 & 4883,9 & 6,1 \\
\hline Донецька & 64698 & 34575 & 36724 & 22782,8 & 29153,3 & $-35544,7$ & $-54,9$ \\
\hline Житомирська & 23250 & 28459 & 31483 & 20342,8 & 23592,9 & 342,9 & 1,5 \\
\hline Закарпатська & 20213 & 24788 & 27320 & 18624,5 & 21897,1 & 1684,1 & 8,3 \\
\hline Запорізька & 41932 & 48177 & 55443 & 36151,3 & 38638,3 & $-3293,7$ & $-7,9$ \\
\hline Івано-Франківська & 27419 & 33806 & 37657 & 19258,2 & 22299,5 & $-5119,5$ & $-18,7$ \\
\hline Київська & 43575 & 55042 & 61998 & 54971,4 & 64917,4 & 21342,4 & 49,0 \\
\hline Кіровоградська & 18022 & 21987 & 25618 & 15374,7 & 16622,5 & $-1399,5$ & $-7,8$ \\
\hline Луганська & 19750 & 8180 & 9127 & 5866,5 & 8236,8 & $-11513,2$ & $-58,3$ \\
\hline Львівська & 45752 & 57520 & 68369 & 51437,4 & 57825,1 & 12073,1 & 26,4 \\
\hline Миколаївська & 23448 & 27532 & 32117 & 19666,8 & 22555,1 & $-892,9$ & $-3,8$ \\
\hline Одеська & 60670 & 72630 & 86054 & 61807,1 & 69196,7 & 8526,7 & 14,1 \\
\hline Полтавська & 26399 & 30567 & 35673 & 25679,5 & 30928,8 & 4529,8 & 17,2 \\
\hline Рівненська & 19652 & 23460 & 25648 & 14927,8 & 17360,0 & -2292 & $-11,7$ \\
\hline Сумська & 19190 & 22872 & 26283 & 16237,5 & 19464,9 & 274,9 & 1,4 \\
\hline Тернопільська & 16737 & 20260 & 22494 & 11651,0 & 13082,8 & $-3654,2$ & $-21,8$ \\
\hline Харківська & 71733 & 84056 & 95904 & 65016,7 & 72517,7 & 784,7 & 1,1 \\
\hline Херсонська & 21208 & 26351 & 29760 & 19109,8 & 21738,7 & 530,7 & 2,5 \\
\hline Хмельницька & 22286 & 26030 & 29825 & 20174,0 & 20565,9 & $-1720,1$ & $-7,7$ \\
\hline Черкаська & 23994 & 27926 & 30812 & 19880,5 & 22495,4 & $-1498,6$ & $-6,2$ \\
\hline Чернівецька & 14637 & 17475 & 18989 & 13553,5 & 15170,4 & 533,4 & 3,6 \\
\hline Чернігівська & 18422 & 21700 & 24745 & 15921,3 & 17973,2 & $-448,8$ & $-2,4$ \\
\hline Київ & 127778 & 161695 & 189628 & 158061,1 & 177101,4 & 49323,4 & 38,6 \\
\hline Севастополь & - & - & - & - & - & - & - \\
\hline
\end{tabular}


Першочергово проведемо аналіз та оцінку обороту роздрібної торгівлі в розрізі регіонів держави (табл. 3). Результати таблиці свідчать, що у цілому по Україні спостерігається позитивна динаміка зростання обороту роздрібної торгівлі, де значення цього показника зросло на 28705,2 млн грн (або на 3,2\%)

Найбільший ріст відбувся у Дніпропетровській області - на 4883,9 млн грн (або на 6,1\%), Закарпатській області - на 1684,1 млн грн (або на 8,3\%), Київській області - на 21342,4 млн грн (або на 49\%), Львівській області - на 12073,1 млн грн (або на 26,4\%), Одеській області - на 8526,7 млн грн (або на 14,1\%), Полтавській області - на 4529,8 млн грн (або на 17,2\%), м. Києві - на 49323,4 млн грн (або на 38,6\%).

Водночас, найбільше скорочення обороту роздрібної торгівлі відбулося у таких регіонах як: Донецькій області - на 35544,7 млн грн (або на 54,9\%), Волинській області - на 5142 млн грн (або на 23,9\%), Луганській області - на 11513,2 млн грн (або на 58,3\%), Тернопільській області - на 3654,2 млн грн (або на 21,8\%).

Практично стійкою залишилась динаміка для Житомирської, Миколаївської, Сумської, Харківської та Херсонської областей.

Основними видами економічної діяльності в сфері роздрібної торгівлі є оптова та роздрібна торгівля автотранспортними засобами та мотоциклами, їх ремонт а також роздрібна торгівля, крім торгівлі автотранспортними засобами та мотоциклами.

Аналізуючи оптову та роздрібну торгівлю автотранспортними засобами та мотоциклами, слід зауважити позитивну динаміку зростання товарообороту протягом аналізованого періоду. В цілому, по Україні товарооборот даного виду економічної діяльності у 2014 році складав 29320 млн грн, у 2018 році значення цього показника зросло на 188054 млн грн і склало 48125,4 млн грн. У регіональному розрізі негативний приріст роздрібного товарообороту підприємств торгівлі спостерігається у Донецькій області (31,6\%), Луганській області (42,1\%) (рис. 2).

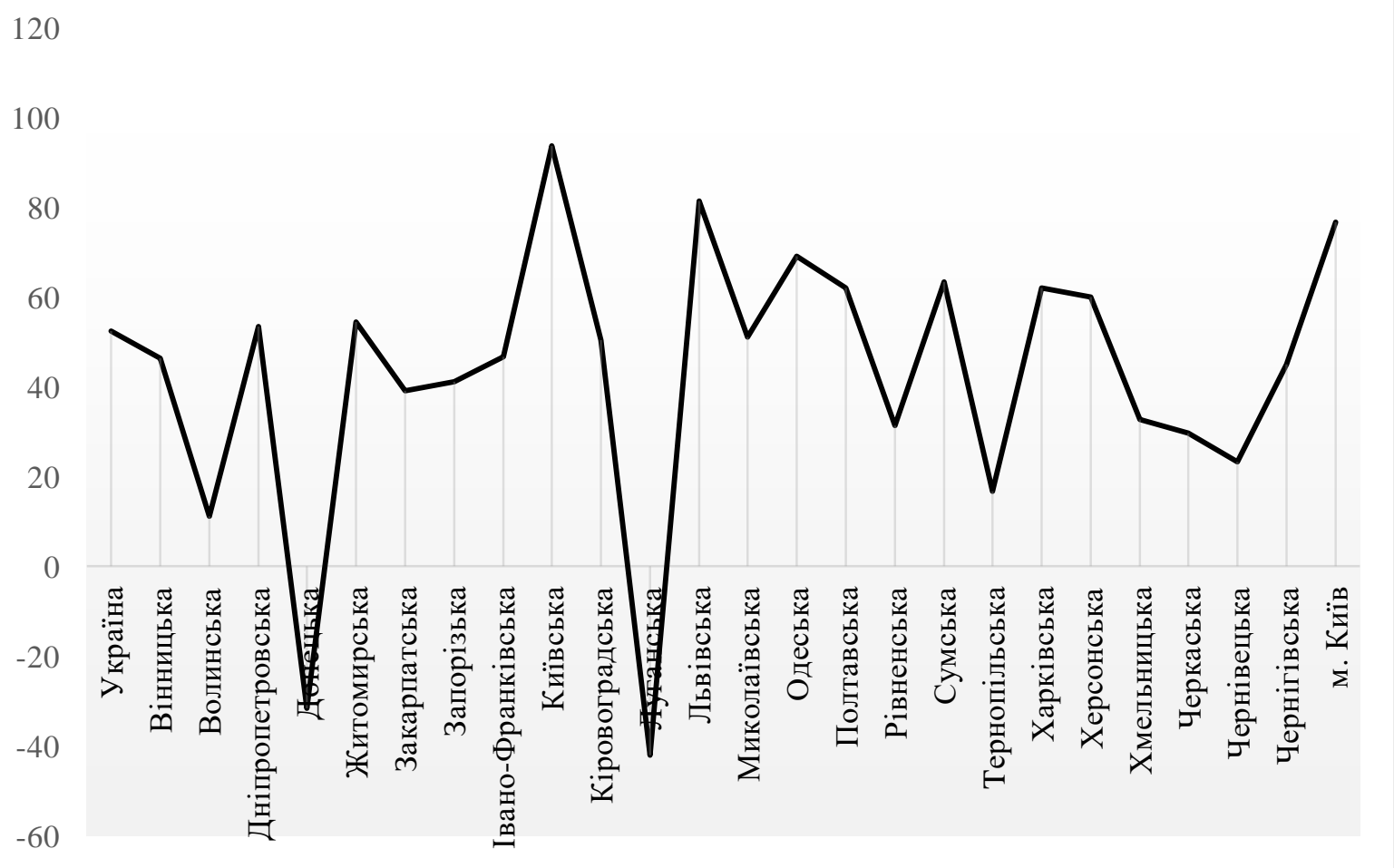

Рис. 2. Схематичне відображення росту (приросту) роздрібного товарообороту підприємств торгівлі регіонів держави у 2018 році 
У решта регіонах держави спостерігається позитивний приріст роздрібного товарообороту підприємств торгівлі. Слід зауважити, що найбільший приріст за аналізований період спостерігався у Дніпропетровській області $(53,4 \%)$, Житомирській області (54,5\%), Київській області (93,8\%), Львівській області $(81,4 \%)$, Одеській області (69,2\%), Полтавській області (62,1\%), Сумській області (63,4\%), м. Києві (76,7\%).

Найвищі індекси спостерігаються у Дніпропетровській, Житомирській, ІваноФранківській, Луганській областях. Слід також зауважити, що у 2014 та 2015 роках спостерігалися відносно невисокі індекси фізичного обсягу роздрібного товарообороту підприємств роздрібної торгівлі. Починаючи із 2016 року можна вже побачити їх зростання у порівнянні із минулим періодом дослідження.

Комплексна оцінка рівня розвитку підприємництва регіонів держави у сфері торгівлі передбачає використання методу стандартизації показників як інструменту зведення різнопланових показників у єдиний інтегральний індекс. Визначення рівня розвитку підприємництва регіонів держави у сфері торгівлі передбачає розрахунок інтегрального індексу передумов розвитку підприємництва регіонів держави у сфері бізнесу та розрахунок інтегрального індексу результатів розвитку підприємництва регіонів держави у сфері бізнесу. Розрахунок інтегрального індексу передумов розвитку підприємництва регіонів держави у сфері торгівлі за період 2014-2018 років наведено у таблиці 4. Схематичне відображення інтегрального індексу передумов розвитку підприємництва регіонів держави у сфері торгівлі у 2018 році наведено на рисунку 3.

Таблиця 4. - Інтегральний індекс передумов розвитку підприємництва регіонів держави у сфері торгівлі за період 2014-2018 років

\begin{tabular}{|l|c|c|c|c|c|}
\hline \multicolumn{1}{|c|}{ Регіони } & $2014 \mathrm{p}$. & $2015 \mathrm{p}$. & $2016 \mathrm{p}$. & $2017 \mathrm{p}$. & $2018 \mathrm{p}$. \\
\hline Вінницька & 0,597 & 0,534 & 0,527 & 0,505 & 0,532 \\
\hline Волинська & 0,422 & 0,448 & 0,448 & 0,432 & 0,399 \\
\hline Дніпропетровська & 0,554 & 0,592 & 0,614 & 0,672 & 0,590 \\
\hline Донецька & 0,278 & 0,233 & 0,227 & 0,257 & 0,219 \\
\hline Житомирська & 0,452 & 0,481 & 0,471 & 0,491 & 0,440 \\
\hline Закарпатська & 0,385 & 0,395 & 0,381 & 0,367 & 0,329 \\
\hline Запорізька & 0,447 & 0,513 & 0,517 & 0,526 & 0,442 \\
\hline Івано-Франківська & 0,366 & 0,384 & 0,385 & 0,368 & 0,313 \\
\hline Київська & 0,726 & 0,751 & 0,770 & 0,758 & 0,781 \\
\hline Кіровоградська & 0,407 & 0,492 & 0,504 & 0,519 & 0,475 \\
\hline Луганська & 0,103 & 0,097 & 0,099 & 0,112 & 0,106 \\
\hline Львівська & 0,657 & 0,698 & 0,713 & 0,776 & 0,676 \\
\hline Миколаївська & 0,343 & 0,411 & 0,435 & 0,470 & 0,402 \\
\hline Одеська & 0,539 & 0,598 & 0,609 & 0,675 & 0,552 \\
\hline Полтавська & 0,478 & 0,517 & 0,524 & 0,536 & 0,490 \\
\hline Рівненська & 0,464 & 0,477 & 0,484 & 0,470 & 0,443 \\
\hline Сумська & 0,343 & 0,394 & 0,380 & 0,400 & 0,343 \\
\hline Тернопільська & 0,328 & 0,370 & 0,362 & 0,373 & 0,313 \\
\hline Харківська & 0,485 & 0,591 & 0,622 & 0,734 & 0,619 \\
\hline Херсонська & 0,361 & 0,446 & 0,451 & 0,478 & 0,403 \\
\hline Хмельницька & 0,477 & 0,518 & 0,530 & 0,550 & 0,458 \\
\hline Черкаська & 0,397 & 0,431 & 0,435 & 0,463 & 0,364 \\
\hline Чернівецька & 0,260 & 0,333 & 0,328 & 0,311 & 0,282 \\
\hline Чернігівська & 0,432 & 0,491 & 0,491 & 0,475 & 0,464 \\
\hline Київ & 0,667 & 0,833 & 0,833 & 1,000 & 0,833 \\
\hline
\end{tabular}


Як бачимо у 2018 році найвищий рівень передумов розвитку підприємництва у сфері торгівлі спостерігався у м. Києві, Київській та Львівській областях. Натомість, найнижчий рівень за цей же період був у Донецькій, Закарпатській, Івано-Франківській, Луганській, Сумській, Тернопільській, Харківській, Чернівецькій областях. Слід зауважити, що динаміка даних показників дещо різнилася за аналізований період, що дозволило згрупувати регіони за рівнем передумов розвитку підприємництва у сфері торгівлі. Таким чином, було виділено три групи регіонів: регіони із низьким рівнем передумов до розвитку підприємництва в сфері торгівлі; регіони зі середнім рівнем передумов до розвитку підприємництва в сфері торгівлі та регіони із високим рівнем передумов до розвитку підприємництва в сфері торгівлі. Якщо, у 2014 році до регіонів із низьким рівнем передумов щодо розвитку підприємництва в сфері торгівлі потрапили такі як Донецька, Луганська, Чернівецька області, то у 2018 році перелік даної групи був значно ширшим, зокрема у цю групу регіонів потрапили додатково Закарпатська, ІваноФранківська, Сумська, Тернопільська, Харківська області.

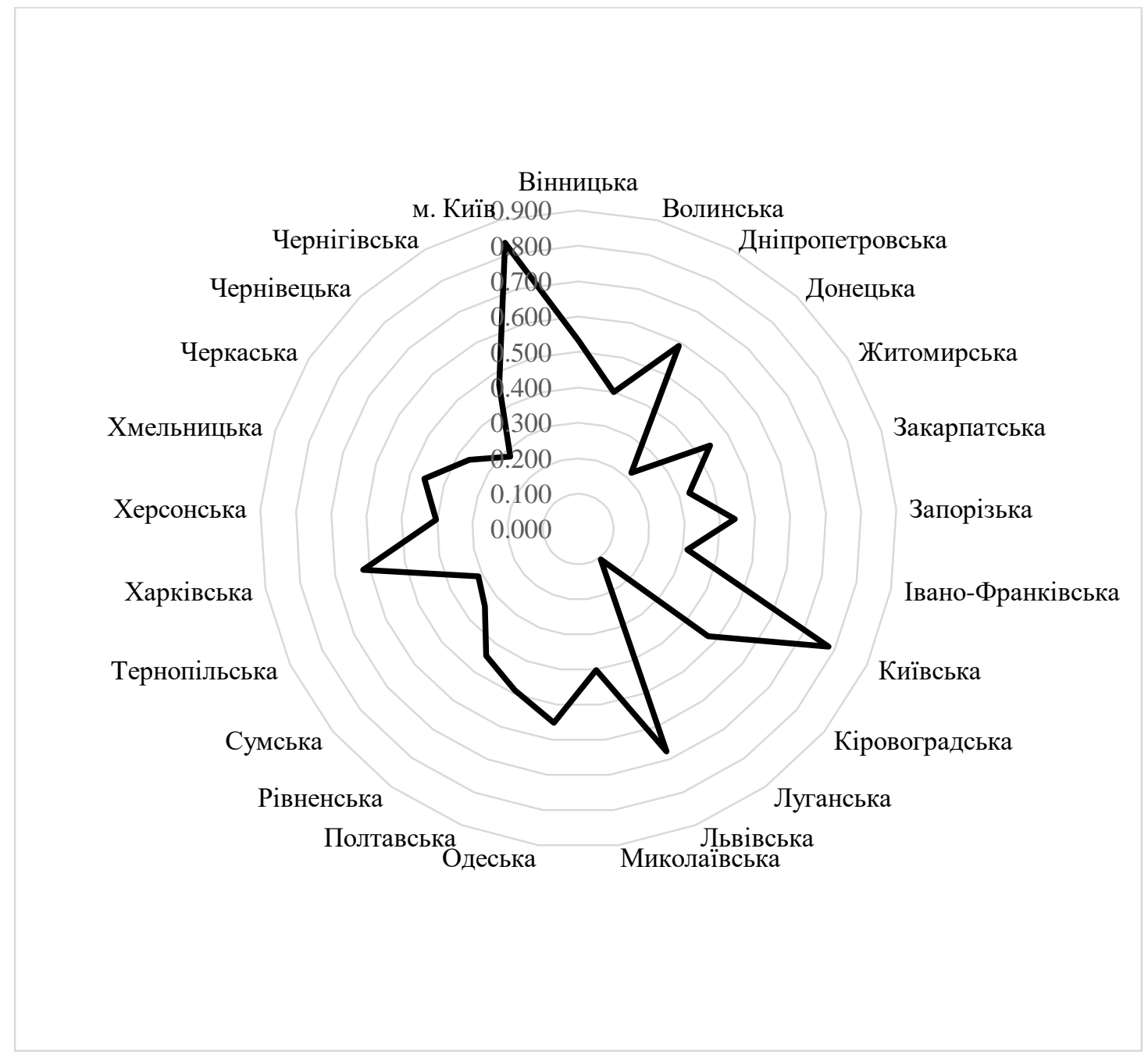

Рис. 3. Схематичне відображення інтегрального індексу передумов розвитку підприємництва регіонів держави у сфері торгівлі у 2018 році

Це вказує на негативні моменти щодо розвитку підприємництва в сфері торгівлі на зазначених територіях та про погіршення підприємницького середовища у цілому. Водночас, зазнала змін і група регіонів, які були віднесені до високого рівня передумов. 
Якщо у 2014 році було п'ять регіонів із високим рівнем передумов розвитку підприємництва в сфері торгівлі (Вінницька, Київська, Львівська, Харківська, м. Київ), то у 2018 році їх кількість склала три (Київська, Львівська, м. Київ). Це теж вказує на зниження підприємницького потенціалу територій. Решта регіонів держави мали середній рівень передумов розвитку підприємництва в сфері торгівлі.

Аналіз та оцінку результатів розвитку підприємництва в сфері торгівлі проведемо за наступною системою показників: оборот роздрібної торгівлі; роздрібний товарооборот підприємств роздрібної торгівлі за видами економічної діяльності; індекси фізичного обсягу роздрібного товарообороту підприємств роздрібної торгівлі.

Розрахунок інтегрального індексу результатів розвитку підприємництва регіонів держави у сфері торгівлі за період 2014-2018 років наведено у таблиці 5. Схематичне відображення інтегрального індексу результатів розвитку підприємництва регіонів держави у сфері торгівлі у 2018 році наведено на рисунку 4.

Отримані результати розрахунків показують, що найвищий рівень результатів розвитку підприємництва в сфері торгівлі мають такі регіони як м. Київ, Київська та Харківська області. Слід зауважити, що рівень результатів розвитку підприємництва в сфері торгівлі за аналізований період 2014-2018 років по регіонах держави залишився практично незмінним. Це підтверджують дані щодо групування регіонів держави за рівнем результатів розвитку підприємництва у сфері торгівлі.

Таблиця 5. - Інтегральний індекс результатів розвитку підприємництва регіонів держави у сфері торгівлі за період 2014-2018 років

\begin{tabular}{|l|c|c|c|c|c|}
\hline \multicolumn{1}{|c|}{ Регіони } & $2014 \mathrm{p}$. & $2015 \mathrm{p}$. & $2016 \mathrm{p}$. & $2017 \mathrm{p}$. & $2018 \mathrm{p}$. \\
\hline Вінницька & 0,342 & 0,290 & 0,292 & 0,270 & 0,270 \\
\hline Волинська & 0,343 & 0,326 & 0,275 & 0,205 & 0,219 \\
\hline Дніпропетровська & 0,593 & 0,537 & 0,525 & 0,508 & 0,518 \\
\hline Донецька & 0,405 & 0,191 & 0,270 & 0,266 & 0,270 \\
\hline Житомирська & 0,327 & 0,268 & 0,264 & 0,263 & 0,257 \\
\hline Закарпатська & 0,329 & 0,289 & 0,267 & 0,269 & 0,251 \\
\hline Запорізька & 0,401 & 0,338 & 0,353 & 0,329 & 0,315 \\
\hline Івано-Франківська & 0,338 & 0,269 & 0,269 & 0,255 & 0,255 \\
\hline Київська & 0,463 & 0,448 & 0,451 & 0,453 & 0,506 \\
\hline Кіровоградська & 0,311 & 0,244 & 0,261 & 0,242 & 0,220 \\
\hline Луганська & 0,178 & 0,088 & 0,214 & 0,194 & 0,221 \\
\hline Львівська & 0,448 & 0,421 & 0,427 & 0,425 & 0,417 \\
\hline Миколаївська & 0,333 & 0,276 & 0,292 & 0,270 & 0,256 \\
\hline Одеська & 0,488 & 0,475 & 0,490 & 0,461 & 0,442 \\
\hline Полтавська & 0,339 & 0,282 & 0,296 & 0,295 & 0,287 \\
\hline Рівненська & 0,326 & 0,261 & 0,241 & 0,228 & 0,230 \\
\hline Сумська & 0,312 & 0,248 & 0,256 & 0,244 & 0,234 \\
\hline Тернопільська & 0,307 & 0,249 & 0,237 & 0,212 & 0,213 \\
\hline Харківська & 0,540 & 0,482 & 0,485 & 0,470 & 0,459 \\
\hline Херсонська & 0,328 & 0,278 & 0,283 & 0,267 & 0,258 \\
\hline Хмельницька & 0,330 & 0,274 & 0,280 & 0,265 & 0,242 \\
\hline Черкаська & 0,321 & 0,267 & 0,264 & 0,254 & 0,236 \\
\hline Чернівецька & 0,306 & 0,245 & 0,231 & 0,230 & 0,219 \\
\hline Чернігівська & 0,311 & 0,246 & 0,253 & 0,242 & 0,221 \\
\hline Київ & 0,980 & 0,982 & 0,997 & 0,991 & 0,966 \\
\hline
\end{tabular}




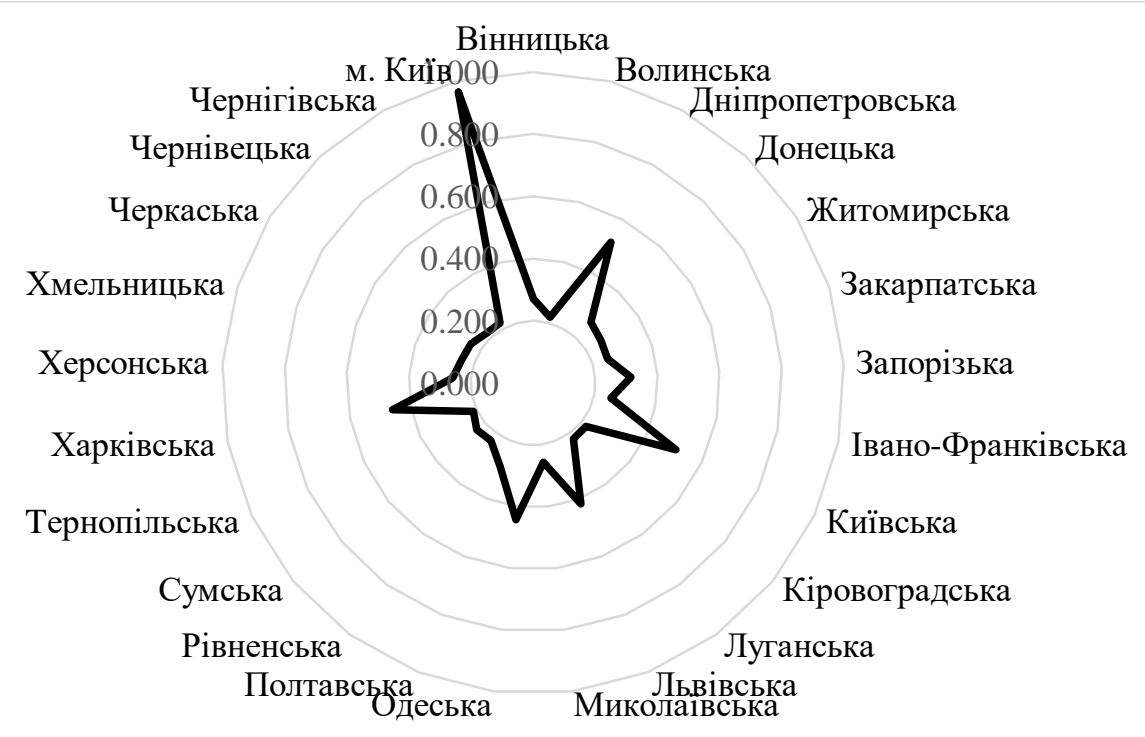

Рис. 4. Схематичне відображення інтегрального індексу результатів розвитку підприємництва регіонів держави у сфері торгівлі у 2018 році

Результати такого групування показують наступне. До регіонів із високим рівнем результатів належить лише м. Київ; до регіонів зі середнім рівнем результатів розвитку підприємництва в сфері торгівлі належать Київська, Харківська області; решта регіонів держави мають низький рівень результатів розвитку підприємництва в сфері торгівлі.

Розраховані інтегральні індекси передумов та результатів розвитку підприємництва в сфері торгівлі дозволили визначити його інтегральний індекс, який наведено у таблиці 6. Схематичне відображення інтегрального індексу розвитку підприємництва регіонів держави в сфері торгівлі у 2018 році наведено на рисунку 5.

Таблиця 6. - Інтегральний індекс розвитку підприємництва регіонів держави у сфері торгівлі за період 2014-2018 років

\begin{tabular}{|l|c|c|c|c|c|}
\hline \multicolumn{1}{|c|}{ Регіони } & $2014 \mathrm{p}$. & $2015 \mathrm{p}$. & $2016 \mathrm{p}$. & $2017 \mathrm{p}$. & $2018 \mathrm{p}$. \\
\hline Вінницька & 0,470 & 0,412 & 0,410 & 0,388 & 0,401 \\
\hline Волинська & 0,382 & 0,387 & 0,362 & 0,318 & 0,309 \\
\hline Дніпропетровська & 0,573 & 0,565 & 0,569 & 0,590 & 0,554 \\
\hline Донецька & 0,341 & 0,212 & 0,248 & 0,261 & 0,244 \\
\hline Житомирська & 0,389 & 0,375 & 0,368 & 0,377 & 0,349 \\
\hline Закарпатська & 0,357 & 0,342 & 0,324 & 0,318 & 0,290 \\
\hline Запорізька & 0,424 & 0,425 & 0,435 & 0,427 & 0,379 \\
\hline Івано-Франківська & 0,352 & 0,326 & 0,327 & 0,311 & 0,284 \\
\hline Київська & 0,594 & 0,600 & 0,611 & 0,605 & 0,644 \\
\hline Кіровоградська & 0,359 & 0,368 & 0,382 & 0,381 & 0,347 \\
\hline Луганська & 0,140 & 0,092 & 0,156 & 0,153 & 0,164 \\
\hline Львівська & 0,552 & 0,560 & 0,570 & 0,601 & 0,547 \\
\hline Миколаївська & 0,338 & 0,343 & 0,363 & 0,370 & 0,329 \\
\hline Одеська & 0,513 & 0,537 & 0,550 & 0,568 & 0,497 \\
\hline Полтавська & 0,409 & 0,400 & 0,410 & 0,415 & 0,388 \\
\hline Рівненська & 0,395 & 0,369 & 0,362 & 0,349 & 0,336 \\
\hline
\end{tabular}


Продовження таблиці 6

\begin{tabular}{|l|c|c|c|c|c|}
\hline \multicolumn{1}{|c|}{1} & 2 & 3 & 4 & 5 & 6 \\
\hline Сумська & 0,328 & 0,321 & 0,318 & 0,322 & 0,289 \\
\hline Тернопільська & 0,318 & 0,309 & 0,299 & 0,293 & 0,263 \\
\hline Харківська & 0,512 & 0,537 & 0,553 & 0,602 & 0,539 \\
\hline Херсонська & 0,344 & 0,362 & 0,367 & 0,372 & 0,331 \\
\hline Хмельницька & 0,403 & 0,396 & 0,405 & 0,407 & 0,350 \\
\hline Черкаська & 0,359 & 0,349 & 0,350 & 0,359 & 0,300 \\
\hline Чернівецька & 0,283 & 0,289 & 0,280 & 0,270 & 0,250 \\
\hline Чернігівська & 0,371 & 0,369 & 0,372 & 0,359 & 0,342 \\
\hline Київ & 0,823 & 0,908 & 0,915 & 0,995 & 0,900 \\
\hline
\end{tabular}

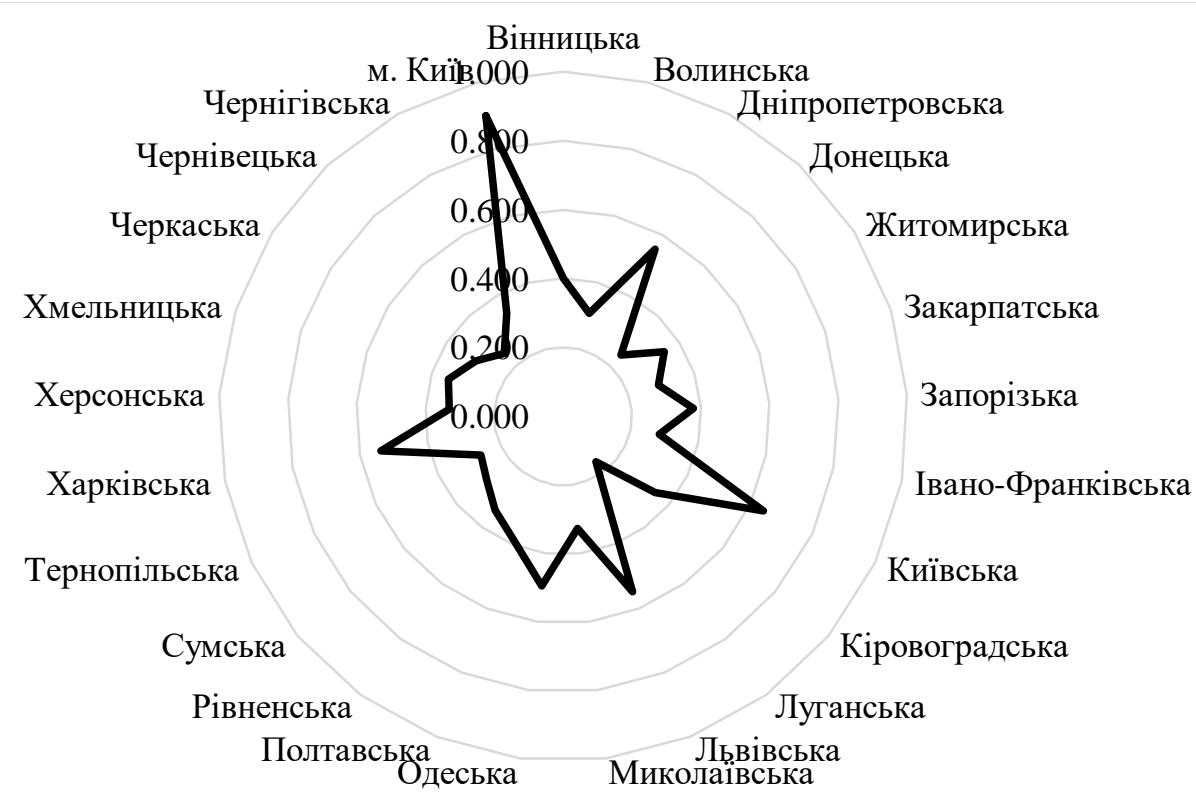

Рис. 5. Схематичне відображення інтегрального індексу розвитку підприємництва регіонів держави в сфері торгівлі у 2018 році

Найвищий рівень розвитку підприємництва у сфері торгівлі спостерігається у м. Києві. Решта регіонів держави розподілилися на середній та низький рівень розвитку підприємництва в сфері торгівлі. Проведене групування за рівнем розвитку підприємництва в сфері торгівлі показує, що незмінним залишився м. Київ. Решта регіонів держави за аналізований період «мігрували» із одного рівня розвитку в інший.

У 2014 році до групи регіонів із середнім рівнем розвитку підприємництва в сфері торгівлі було віднесено Вінницька, Волинська, Дніпропетровська, Житомирська, Київська, Запорізька, Львівська, Одеська, Полтавська, Рівненська, Харківська Хмельницька області. У 2018 році ситуація значно погіршилася, в результаті чого частина регіонів (Вінницька, Волинська, Житомирська, Запорізька, Полтавська, Рівненська, Хмельницька області) потрапили до групи із низьким рівнем розвитку підприємництва в сфері торгівлі.

Загальну ситуацію щодо рівнів передумов, результатів та розвитку підприємництва регіонів держави в сфері торгівлі можна простежити за даними, наведеними у таблиці 7. 
Таблиця 7. - Оцінка рівнів передумов, результатів та розвитку підприємництва регіонів держави в сфері торгівлі у 2018 році

\begin{tabular}{|c|c|c|c|c|c|c|c|c|c|}
\hline \multirow{2}{*}{ Регіони } & \multicolumn{3}{|c|}{$\begin{array}{l}\text { Інтегральний індекс } \\
\text { передумов }\end{array}$} & \multicolumn{3}{|c|}{$\begin{array}{l}\text { Інтегральний індекс } \\
\text { результатів }\end{array}$} & \multicolumn{3}{|c|}{$\begin{array}{l}\text { Інтегральний індекс } \\
\text { розвитку }\end{array}$} \\
\hline & $\mathrm{H}$ & $\mathrm{c}$ & B & $\mathrm{H}$ & $\mathrm{c}$ & B & $\mathrm{H}$ & $\mathrm{c}$ & в \\
\hline Вінницька & & + & & + & & & + & & \\
\hline Волинська & & + & & + & & & + & & \\
\hline Дніпропетровська & & + & & + & & & + & & \\
\hline Донецька & + & & & + & & & & + & \\
\hline Житомирська & & + & & + & & & + & & \\
\hline Закарпатська & + & & & + & & & + & & \\
\hline Запорізька & & + & & + & & & + & & \\
\hline Івано-Франківська & + & & & + & & & + & & \\
\hline Київська & & & + & & + & & & + & \\
\hline Кіровоградська & & + & & + & & & + & & \\
\hline Луганська & + & & & + & & & + & & \\
\hline Львівська & & & + & + & & & & + & \\
\hline Миколаївська & & + & & + & & & + & & \\
\hline Одеська & & + & & + & & & & + & \\
\hline Полтавська & & + & & + & & & + & & \\
\hline Рівненська & & + & & + & & & + & & \\
\hline Сумська & + & & & + & & & + & & \\
\hline Тернопільська & + & & & + & & & & & \\
\hline Харківська & + & & & & + & & & + & \\
\hline Херсонська & & + & & + & & & + & & \\
\hline Хмельницька & & + & & + & & & + & & \\
\hline Черкаська & & + & & + & & & + & & \\
\hline Чернівецька & + & & & + & & & + & & \\
\hline Чернігівська & & + & & + & & & + & & \\
\hline Київ & & & + & & & + & & & + \\
\hline
\end{tabular}

Висновки. Як бачимо, простежується неоднозначна ситуація щодо наведених рівнів. Спостерігається група регіонів, які мають низькі передумови розвитку підприємництва в сфері торгівлі, проте характеризуються середнім рівнем результатів та розвитку в цілому (Донецька, Харківська області). Це свідчить про те, що незважаючи на низькі можливості, регіони все ж таки знаходять шляхи максимально ефективного їх використання та забезпечення високих показників результативності торгівлі. Водночас, $\epsilon$ регіони, що володіють потенційними можливостями та передумовами та, одночас, мають невисокі показники результативності (Вінницька, Волинська, Дніпропетровська, Житомирська, Запорізька, Київська, Львівська, Миколаївська, Одеська, Полтавська, Рівненська, Херсонська, Хмельницька, Черкаська, Чернігівська області). Це свідчить про низький рівень ефективності використання своїх потенційних можливостей та про необхідність прийняття обгрунтованих рішень по підвищенню ефективності їх використання.

\section{Список бібліографічного опису}

1.Васільєва Л.М. Поняття і сутність підприємництва. Вісник Дніпропетровського держсавного аграрного університету. 2010. №1. С.175-178.

2.Власова Н.О., Чорна М.В., Бєляєва М.В. Економічний механізм регулювання підприємницької діяльності в роздрібній торгівлі: монографія. Харків: ХДУХТ, 2013. 155c.

3.Сизоненко В. Теорія підприємництва: здобутки і проблеми дослідження. Економіка України. 2002. № 9. С. 45-51.

4.Андросова Т.В. Торгівля в ринковій економіці: навч. посібник. Харків: ХДУХТ, 2001. 120 с.

5.Бурак І.О. Концептуальні підходи до визначення сутності та видів торговельної діяльності. Молодий вчений. 2016. №3(30).

6.Власова Н.О., Красноусов А.В. Теоретичні аспекти змісту «комерційної діяльності» підприємств торгівлі. Економіка розвитку. ХНЕУ. 2005. № 2 (34). С. 66-68.

7.Панкратов Ф.Г., Серьогіна Т.К. Комерційна справа: навч. посібник. 2-ге вид., випр. Рівне: Вертекс, 2009. 352 с.

8.Саблук О. Суть і принципи комерційного підприємництва і комерційної діяльності. Науковий вісник МНУ імені В.O. Сухомлинського. Економічні науки. 2018. № 1 (10). 


\title{
References
}

1. Vasilieva L.M. Poniattia i sutnist pidpryiemnytstva. Visnyk Dnipropetrovskoho derzhavnoho ahrarnoho universytetu. 2010. No.1. p.175-178 [in Ukrainian].

2. Vlasova N.O., Chorna M.V., Bieliaieva M.V. Ekonomichnyi mekhanizm rehuliuvannia pidpryiemnytskoii diialnosti v rozdribnii torhivli: monohrafiia. Kharkiv:KHDUKHT, 2013. 155 p. [in Ukrainian].

3. Syzonenko V. Teoriia pidpryiemnytstva: zdobutky I problem doslidzhennia. Ekonomika Ukrainy.2002. No.9 p.45-51 [in Ukrainian].

4. Androsova T.V. Torhivlia v rynkovii ekonomitsi: navch. Posibnyk. Kharkiv: KHDUKHT, 2001. 120 p. [in Ukrainian].

5. Burak I.O. Kontseptualni pidkhody do vyznachennia sutnosti ta vydiv torhovelnoi diialnosti. Molodyi vchenyi. 2016. No.3(30). [in Ukrainian].

6. Vlasova N.O., Krasnousov A.V. Teoretychni aspekty zmistu „komertsiinio diialnosti” pidpryiemstv torhivli. Ekonomika rozvytku. KHNEU. 2005. No.2 (34). P. 66-68.

7. Pankratov F.H., Sierohina T.K. Komertsiina sprava: navchalnyi osibnyk. 2-he vydannia, vypravlene Rivne: Verteks, 2009. 352 p. [in Ukrainian].

8. Sabluk O. Sut i pryntsypy komertsiinoho pidpryiemnytstva i komertsiinoi diialnosti. Naukovyi visnyk MNU imeni V.O. Sukhomlynskoho. Ekonomichni nauky. 2018. No.1(10) [in Ukrainian].

Дата подання публікації 25.12.2020 р.

Косінський П.М., доктор філософії Асистент кафедри економіки Kosinskyi P., $\mathrm{PhD}$ Assistant of the Department of Economics https://orcid.org/0000-0002-3254-2379

\section{ОЦІНКА НЕОБХІДНОСТІ ЗАСТОСУВАННЯ ДОДАТКОВИХ ЕКОНОМІЧНИХ ІНСТРУМЕНТІВ ЗНИЖЕННЯ ВИКИДІВ І ВІДХОДІВ ПЕРЕРОБНИХ ВИРОБНИЦТВ У РЕГІОНІ}

\author{
Луиьький національний технічний університет
}

\begin{abstract}
В статті розглядається питання, що стосується застосування додаткових економічних стимулів як засобів впливу на зниження викидів і відходів переробних виробництв регіону, що працюють на місцевій природно-ресурсній сировині. Визначено фактори, які впливають на викиди шкідливих речовин та відходів у навколишне природне середовище. Узагальнено «основні проблеми функціонування системи стимулювання поглибленої переробки природних ресурсів еколого-економічного характеру. Виявлено, що у Волинській області спостерігається переважно позитивна тенденція до збільшення масштабів поглибленої переробки природної сировини, а також доцільності збільшувати бюджетні видатки на розвиток сільського, лісового та рибного господарства, адже це дасть позитивний соціально-економічний результат. Вивчено й проаналізовано тенденції стосовно зміни обсягів реалізації промислової продукції та зміни обсягів викиду шкідливих речовин і відходів, на основі показників реальних обсягів реалізації продукції підприємств харчової та деревообробної сфери, дослідження яких показало, що за останнє десятиріччя обсяг реалізованої продукції підприємствами деревообробної та харчової сфер промисловості регіону поступово зростав, при чому обсяг відходів та викидів шкідливих речовини, в наслідок їхньої діяльності, поступово зменшувався, що, зрештою, дає можливість говорити про певний розвиток поглибленої переробки природних деревинних ресурсів і сільськогосподарської сировини у Волинській області. Проведено порівняння показників співвідношення обсягів виробництва (реалізації) продукції підприємствами, що переробляють місцеву природно-ресурсну сировину до суми обсягів відходів виробництва й викиду шкідливих речовин в звітному році із середнім зваженим значенням даного показника за період 2010-2018 pp. Таким чином, коли щорічний показник співвідношення обсягів реалізації продукції підприємствами, до сумарного обсягу відходів виробництва й викиду шкідливих речовин більший за середнє зважене значення, то відпадає потреба у залученні додаткових економічних інструментів зниження обсягів забруднюючих речовин, але, якщо даний показник є меншим за середнє зважене значення, то залучення додаткових економічних інструментів зниження викидів і відходів переробних виробництв у регіоні є просто необхідним. У зв'язку з цим, запропоновано використовувати відповідні фінансово-економічні інструменти заохочувального та карального характеру.
\end{abstract}

